\title{
A Novel Computational Model for Organic PV Cells and Modules
}

\author{
Han Huang ${ }^{1}$, Noel Bristow ${ }^{2}$, Tudur Wyn David ${ }^{2}$, Jeff Kettle ${ }^{3}$ and Grazia Todeschini ${ }^{1}{ }_{\ddagger}$ \\ ${ }^{1}$ College of Engineering, Swansea University, Swansea, United Kingdom \\ ${ }^{2}$ School of Computer Science and Electronic Engineering, Bangor University, Bangor, United Kingdom \\ ${ }^{3}$ James Watt School of Engineering, University of Glasgow, United Kingdom \\ han.huang@swansea.ac.uk; eesa10@bangor.ac.uk; eepa2a@,bangor.ac.uk; Jeff.Kettle@glasgow.ac.uk; grazia.todeschini@swansea.ac.uk
}

¥Corresponding Author; Grazia Todeschini, mirfanabid@riphahfsd.edu.pk

Received: 30.10.2020 Accepted:11.12.2020

\begin{abstract}
This paper presents a detailed single-diode based computational PV model for organic photovoltaic (OPV) cells. These cells employ organic semiconductor materials, and while they cheaper and lighter than conventional PV cells, they suffer of low fill-factor and cannot be described by conventional models. The mathematical model of the OPV cells and the calculation of its parameters are described in the first part of the paper. Then the calculation of model parameters for PV cells is outlines and implementation of the model in MATLAB is presented. Simulation results are compared with outdoor test data and indicate that the proposed model is able to duplicate the behavior of the OPV cells accurately, with a maximum error of $3.9 \%$. Following this result, further validation is carried out for a larger module including 512 cells for two different days, with a maximum error of $5.9 \%$, thus confirming the accuracy and scalability of the proposed model.
\end{abstract}

Keywords: organic photovoltaic cells, PV model, fill factor

\section{Introduction}

Environmental concerns and reduced costs motivate the demand for the increase usage of renewable energy sources (RESs) for power generation. The photovoltaic (PV) cell has become one of the main technologies that support this transition. As PV cells can be deployed anywhere, and can be easily integrated in existing architecture, such as in the case of roof-top solar, they gained increasing popularity $[1,2]$, Another factor that contributed to the success of this technology is the reduction of cost of utility-scale solar PVs, that decreased by approximately by two thirds between 2010 and 2015 [3].

The first generation of PV materials were based on silicon [4]. The second generation included thin-film technologies to reduce the cost. More recently, a third generation was developed, that employs exitonic materials. This generation covers a broad range of technologies including organic photovoltaics (OPVs), dye-sensitised solar cell (DSSC), perovskite and quantum dots [5]. The comparison of PV cells and modules deploying varying materials and under varying operating conditions is a complex task, to various factors, including: manufacturing cost, size of the panels, and environmental conditions (irradiance, temperature, cloudiness etc.) [6-9].

The above challenges have been overcome by development of PV emulators, that consist of power electronic circuit-based models $[10,11]$. Emulators are able to replicate the non-linear current-voltage (I-V) characteristic of PV cells in a simulation environment. Numerous PV emulators have been documented but in general, all of these devices consist of three main parts: the PV model, the control algorithm and the power converter [6, 12-14]. The model is the central component that allows testing different characteristics of the PV panels.

The circuit-based PV model described in [10] derive the PV cell I-V characteristic by using Kirchhoff current law [15]. The circuit includes a current source, a diode, a series and a shunt resistor and it can be used to represent a broad range of PV module. In [12], the authors proposed a resistance feedback strategy to control a buck converter-based emulator and validated by comparing with a PV panel. In [13], a fractional order robust control method was proposed to enhance the controllability of a double diode PV emulator model - the model was developed to improve the accuracy under variable irradiation effects [16]. Most of the research carried out in the literature focus on the control schemes and emulator model. However, in terms of low fill factor (FF) 
material PV cells, such as OPVs, there is still a research gap in the area of developing accurate models to be used in both simulation environments and emulators.

This paper describes an improved single-diode approximation-based model that allows replicating three different OPV cell module types. The single-diode approximation algorithms is the pioneering concept of PV cells modeling [17] and it is revised in Section 2. The calculation of the parameters for three OPV cells is shown in Section 3. Section 4 presents the computer model developed for the OPV cells and will compare simulated results with outdoor test data. Voltage, current and power have been monitored in an outdoor location with varying environmental conditions [18]. These measurements are compared with the results obtained from the computer model and the error is calculated. Finally, the analysis will be extended to a large module in Section 5: in this case, appropriate scaling is applied to the model and comparison between experimental results for two different days are carried out. The comparison between experimental results and outdoor test data shows a maximum error in fill factor equal to $3.9 \%$ for individual cells, and equal to $5.9 \%$ for the large model. Errors on other parameters (such as maximum power) are smaller, and this confirm the validity of the proposed approach.

\section{PV Cell Model Description}

An organic photovoltaic cell consists of a donor-acceptor absorbing layer with transport layers and electrical contacts applied on either side of the absorbing layer. The donoracceptor layer absorbs the incoming photons and, if the energy absorbed by the electron is equal or greater than the bandgap, an exciton is formed. At the interface between the donoracceptor materials, the exciton can be separated to enable current flow in the cell.

Various diode approximation-based models have been proposed to represent the electrical behaviour of OPV cells $[14,19]$. The ideal equivalent model and a more realistic equivalent model that takes into account non-idealities are presented in the next sections.

\subsection{Ideal cell equivalent circuit model}

Fig. 1 shows the equivalent circuit for an ideal PV cell. It includes a current source $I_{p h}$, representing the electrons from PV material, and a diode connected in parallel. The diode current $I_{D}$ can be expressed by Shockley's diode equation:

$$
I_{D}=I_{o}\left[\left(e^{\frac{q V p v}{n k N_{S} T_{C}}}\right)-1\right]
$$

where $q=$ electron charge, $k=$ Boltzman constant, $N_{s}=$ number of cells in series per module, $V_{p v}=$ terminal voltage, $n=$ junction ideality factor, $T_{c}=$ measured cell temperature. The reverse saturation current $I_{o}$ is expressed as follows:

$$
I_{o}=\frac{I_{S c}}{e^{\frac{q V_{o c}}{n k N_{S} T_{c}}-1}}
$$

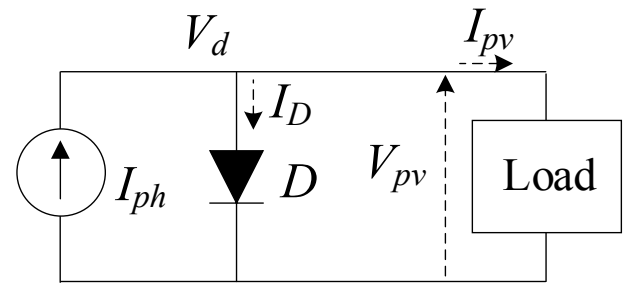

Fig. 1 Simplified PV model.

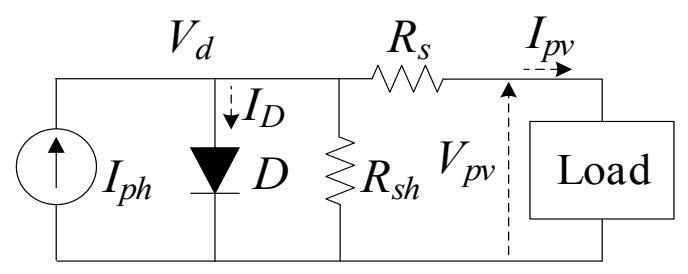

Fig. 2 Complete PV model.

where $V_{o c}=$ open circuit voltage, $I_{s c}=$ short circuit current at the reference temperature.

The current $I_{p h}$ depends on the cell temperature and irradiance according to the equation:

$$
I_{p h}=I_{s c}+k_{i}\left(T_{c}-T_{r e f}\right) \frac{s}{s_{r e f}}
$$

where $k_{i}=$ temperature coefficient of photon current,,$T_{r e f}=$ reference cell temperature, $S=$ actual cell irradiance, $S_{r e f}=$ reference cell irradiance.

As a result, referring to Fig. 1, the terminal current is expressed as:

$$
I_{p v}=I_{p h}-I_{D}
$$

This model is commonly used for simplified studies of PV cells.

\subsection{Non-ideal cell equivalent circuit model}

A non-ideal PV cell can be modelled by introducing two additional components to the equivalent circuit: the shunt resistance and the series resistance [20]. These two resistances allow modelling the impact of non-idealities on the I-V characteristics and efficiency of cells, and they are shown in Fig. 2 as $R_{s}$ and $R_{s h}$.

When the shunt resistance $R_{s h}$ is connected, the photon current $I_{p h}$ generated by PV material will be partly drawn by it, which will result in a reduction in the power that flowing to the load. The terminal current for the model shown in Fig. 2 is calculated as follows:

$$
I_{p v}=I_{p h}-I_{D}-I_{s h}
$$

where the current flowing through shunt resistance is $I_{s h}$ and calculated as:

$$
I_{s h}=\frac{V_{p v}+I_{p v} R_{S}}{R_{S h}}
$$




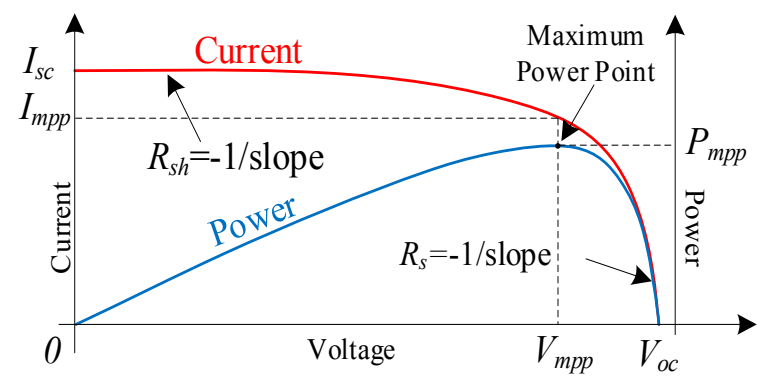

Fig. $3 \mathrm{I}-\mathrm{V}$ and P-V curves with main parameters shown.

Also, the resistances introduced in the model will affect the diode current $I_{D}$ and photon current $I_{p h}$ in order to replicate cell non-idealities, therefore, the conventional PV model equations in (1) and (3) are modified as follows:

$$
\begin{aligned}
& I_{D}=I_{o}\left[\left(e^{\frac{q\left(V p v+I p v R_{S}\right)}{n k N_{S} T_{c}}}\right)-1\right] \\
& I_{p h}=\left[I_{s c}+\frac{I_{s c} R_{S}}{R_{S h}}+k_{i}\left(T_{c}-T_{\text {ref }}\right) \frac{s}{s_{r e f}}\right]
\end{aligned}
$$

Thus, the terminal current $I_{p v}$ is obtained as

$$
\begin{aligned}
I_{p v} & =I_{s c}+k_{i}\left(T_{c}-T_{r e f}\right) \frac{s}{S_{r e f}} \\
& -I_{o}\left[\left(e^{\frac{q\left(V p v+I p v R_{S}\right)}{n k N_{S} T_{c}}}\right)-1\right]-\frac{V_{p v}+\left(I_{p v}-I_{s c}\right) R_{s}}{R_{S h}}
\end{aligned}
$$

The formulation described above will be adopted in this paper to represent the behaviour of the OPV cells.

\section{Calculation of Parameters for OPV Cells}

This section shows the calculation of the model parameters for three OPV cells. The cells are referred to as 'AgGrid', 'AgNW' and 'Carbon'. The three cells are differentiated by their electrode design and the detailed description of their characteristics is reported in [4]. For 'AgGrid' and 'AgNW', 8 cells are monolithically connected in series consisting of a silver grid or silver nanowire front electrode, respectively, while a Carbon based screen printed electrode with 16 cells is used for the final module type. These cells have been selected since outdoor test data are available.

The shunt resistance and series resistance $R_{s}$ and $R_{s h}$ shown in Fig. 3 are calculated based on the shape of the I-V characteristic. More specifically, $R_{s h}$ is calculated on the initial slope, and $R_{S}$ is calculated based on the final slope, as shown in Fig. 5.

The cell temperature $T_{c}$ is calculated according to the following equation:

$$
T_{c}=T_{o t}+k_{\text {ros }} S
$$

where $T_{c}$ is the OPV cell temperature, $T_{o t}$ is the ambient temperature, $S$ is irradiance and $k_{\text {ros }}$ is the Ross Coefficient.
This coefficient can be obtained from previous outdoor tests as shown in Fig. 6 [18]. The coefficient drops with wind speed increases in a nonlinear rate, until to a constant at wind speed above $5 \mathrm{~m} / \mathrm{s}$. For instance, when wind speed is $0.5 \mathrm{~m} / \mathrm{s}$, $k_{\text {ros }}=0.027 \mathrm{~K} . \mathrm{m}^{2} / \mathrm{W}$; when wind speed is $5.8 \mathrm{~m} / \mathrm{s}, k_{\text {ros }}=$ $0.011 \mathrm{~K} . \mathrm{m}^{2} / \mathrm{W}$.

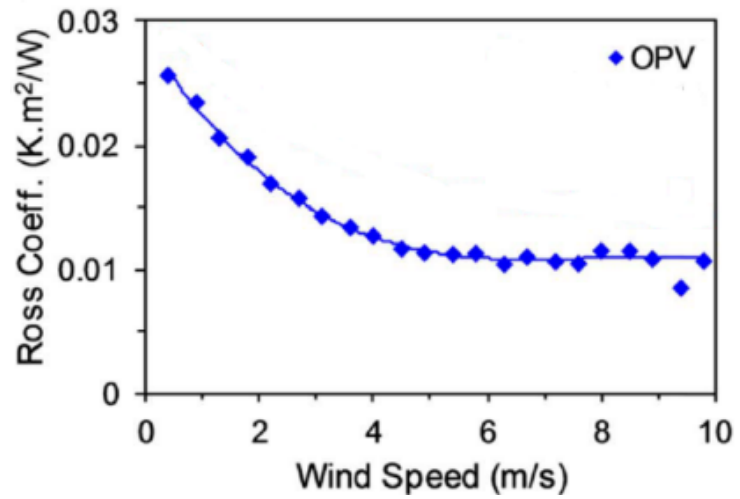

Fig. 4 OPV Ross Coefficient as a function of wind speed using data supplied from [18].

Table 1. OPV parameters for temperatures calculation

\begin{tabular}{|c|c|c|c|}
\hline & AgGrid & AgNW & Carbon \\
\hline$T_{\text {ot }}$ & $18.2^{\circ} \mathrm{C}$ & $11.2^{\circ} \mathrm{C}$ & $18.3^{\circ} \mathrm{C}$ \\
\hline$S$ & $831 \mathrm{~W} / \mathrm{m}^{2}$ & $1006.66 \mathrm{~W} / \mathrm{m}^{2}$ & $949.2 \mathrm{~W} / \mathrm{m}^{2}$ \\
\hline $\begin{array}{c}\text { Wind } \\
\text { speed }\end{array}$ & $5.8 \mathrm{~m} / \mathrm{s}$ & $4 \mathrm{~m} / \mathrm{s}$ & $2.2 \mathrm{~m} / \mathrm{s}$ \\
\hline$k_{\text {ros }}$ & $\begin{array}{c}0.011 \mathrm{~K}^{*} \\
\mathrm{~m}^{2} / \mathrm{W}\end{array}$ & $\begin{array}{c}0.013 \mathrm{~K}^{*} \\
\mathrm{~m}^{2} / \mathrm{W}\end{array}$ & $\begin{array}{c}0.02 \mathrm{~K}^{*} \\
\mathrm{~m}^{2} / \mathrm{W}\end{array}$ \\
\hline$T_{c}$ & $26.59{ }^{\circ} \mathrm{C}$ & $24.29{ }^{\circ} \mathrm{C}$ & $37.28{ }^{\circ} \mathrm{C}$ \\
\hline
\end{tabular}

Table 2. Cell parameters used in the computer model.

\begin{tabular}{|c|c|c|c|}
\hline & AgGrid & AgNW & Carbon \\
\hline$N_{s}$ & 8 & 8 & 16 \\
\hline$N_{s h}$ & 1 & 1 & 1 \\
\hline$R_{s}$ & $63 \Omega$ & $25 \Omega$ & $479 \Omega$ \\
\hline$R_{s h}$ & $516 \Omega$ & $651 \Omega$ & $1420 \Omega$ \\
\hline$V_{o c}$ & $4.19 \mathrm{~V}$ & $4.55 \mathrm{~V}$ & $7.65 \mathrm{~V}$ \\
\hline$I_{S C}$ & $20.40 \mathrm{~mA}$ & $53.86 \mathrm{~mA}$ & $8.52 \mathrm{~mA}$ \\
\hline
\end{tabular}

Based on (10), the temperature for the three OPV cells considered in this work can be obtained as shown in Table 1. The cell temperature $T_{c}$ is critical for the accuracy of the model as it used to calculate various parameters, as indicated in (7), (8) and (9). The summary of the OPV cells parameters is shown listed in Table 2.

\section{Simulation Results for the Three OPV Cells}

\subsection{MATLAB Model}

The model described is Section 2 is implemented in MATLAB/Simulink. An overview of the model is shown in Fig 3. Based on the values of the cell parameters and the operating point, the mathematic model will determine the value of $I_{p v}$ to be sent to a controlled voltage source. The 
voltage source included in the model provides the potential

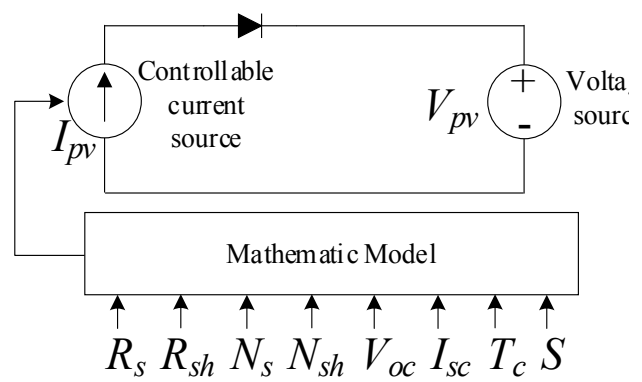

Fig. 5 Overview of the model and the simulation circuit.

difference for the photon current to flow.

The details of the mathematic model are shown in Fig. 4: the definition of the numerical constants is included in Fig. 4(a). The shunt current $I_{s h}$ (6) is calculated as shown in Fig. 4(b), the diode current $I_{D}$ is calculated in Fig. 4(c) and the source current $I_{p h}$ is illustrated in Fig. 4(d). Finally, $I_{p v}$ can be derived as $\left(I_{p h}-I_{D}-I_{s h}\right)$.

The values of the constants are listed in Table 3, while other parameters $\left(N_{s}, N_{s h}, R_{s}, R_{s h}, T_{c}, S, V_{o c}\right.$ and $\left.I_{s c}\right)$ depend on the considered OPV cell, as illustrated in Table 2.

\subsection{Comparison of simulated and experimental results}

Table 3. Values of the constants defined in the model.

\begin{tabular}{|c|c|}
\hline Term & Value \\
\hline$q$ & $1.6 \times 10^{-19} \mathrm{C}$ \\
\hline$k$ & $1.38 \times 10^{-23} \mathrm{~J} / \mathrm{K}$ \\
\hline$n$ & 1.47 \\
\hline$k_{i}$ & $1.7 \times 10^{-3} \mathrm{~A} / \mathrm{K}$ \\
\hline$T_{r e f}$ & $25^{\circ} \mathrm{C}$ \\
\hline$S_{r e f}$ & $1000 \mathrm{~W} / \mathrm{m}^{2}$ \\
\hline
\end{tabular}

The simulation results obtained from the computer model and the outdoor test data for the AgGrid OPV cells, AgNW OPV cells and Carbon OPV cells are compared in Fig. 7, Fig. 8 and Fig. 9, respectively. In all figures, (a) corresponds to the $\mathrm{I}-\mathrm{V}$ curves and (b) corresponds to the P-V curves. The blue curves represent the results obtained with the MATLAB/Simulink model, the red curves are the outdoor test data. The outdoor test data have been collected during the month of August 2018 for various levels of irradiance and for various temperatures.

The comparison is summarised in Table 4 by means of a few key parameters: maximum power $\left(P_{m p}\right)$, voltage at maximum power $\left(V_{m p}\right)$, current at maximum power $\left(I_{m p}\right)$, and Fill Factor $(F F)$. The fill factor is calculated as shown below:

$$
F F=\frac{P_{m p}}{V_{o c} I_{s c}}
$$

As it can be observed from the results in Table 4, the Fill Factor of the cells is low, and this is a well-known limitation

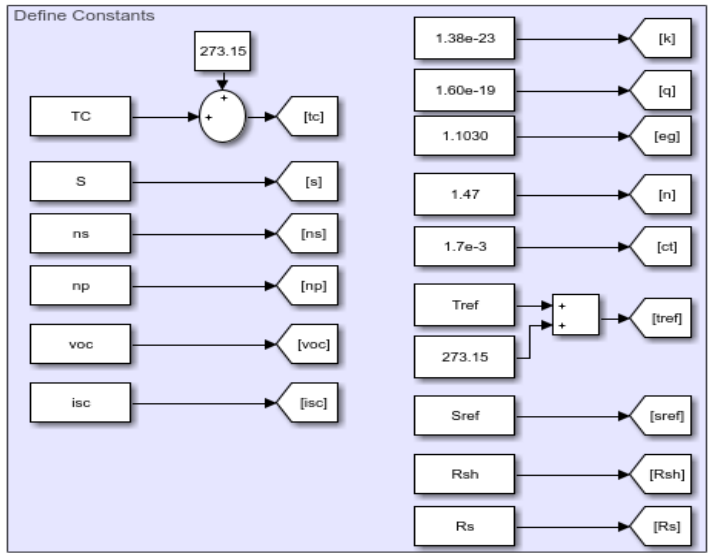

(a)

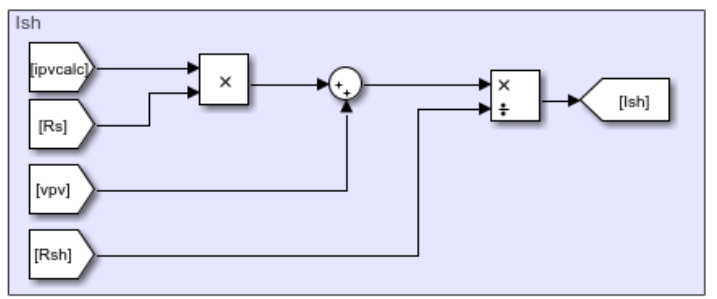

(b)

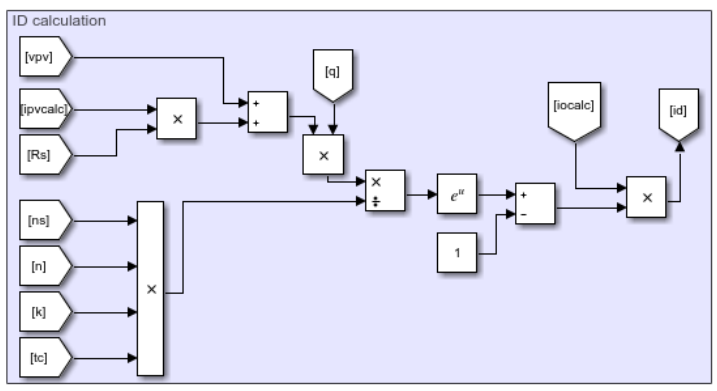

(c)

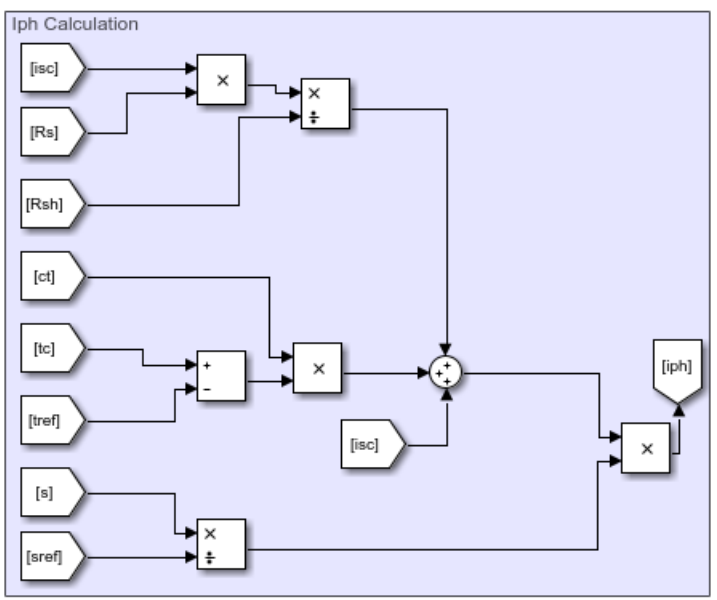

(d)

Fig. 6 Details of the mathematical model: (a) Definition of the constants, (b) Shunt current $I_{s h}$ calculation, (c) Diode current $I_{D}$ calculation and (d) Source current $I_{p h}$ calculation. 
of OPV cells [21]. However, the proposed model allows calculating accurately this parameter, as well as the maximum power $\left(P_{m p}\right)$, the maximum voltage $\left(V_{m p}\right)$ and the maximum current $\left(I_{m p}\right)$. The best fittings are obtained for the AgNW cell.

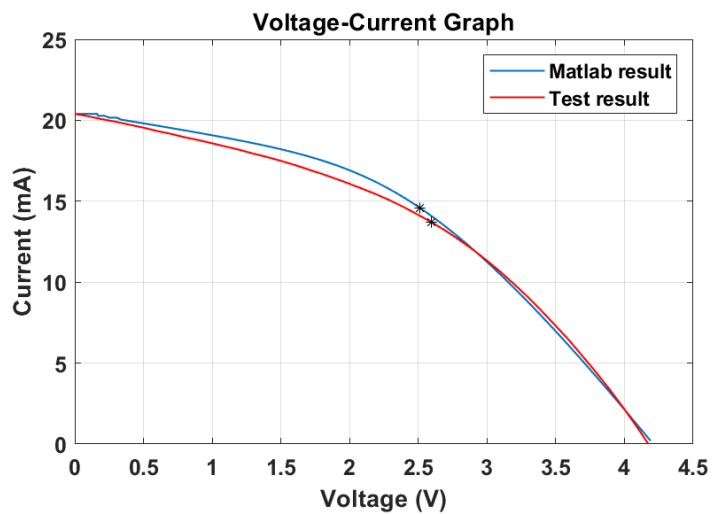

(a)

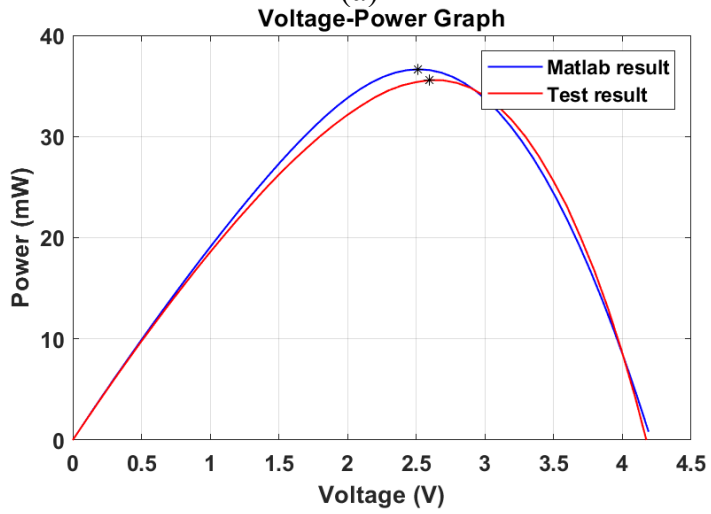

(b)

Fig. 7 Results for AgGrid OPV (a) I-V and (b) P-V curves.

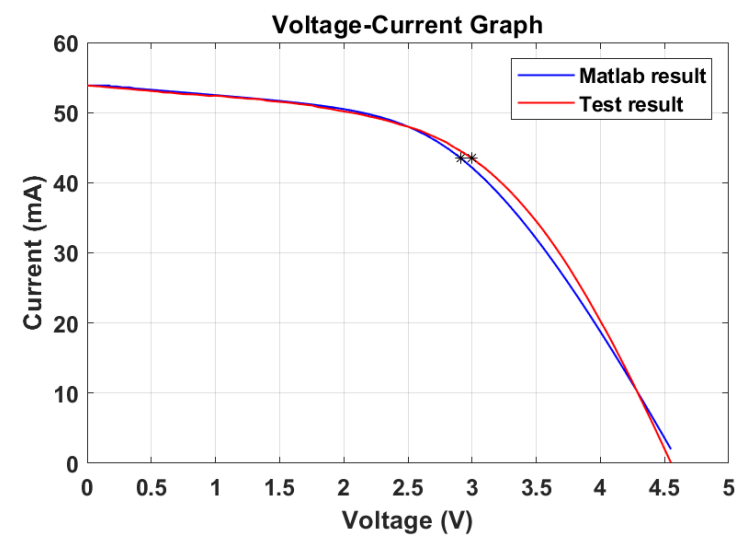

(a)

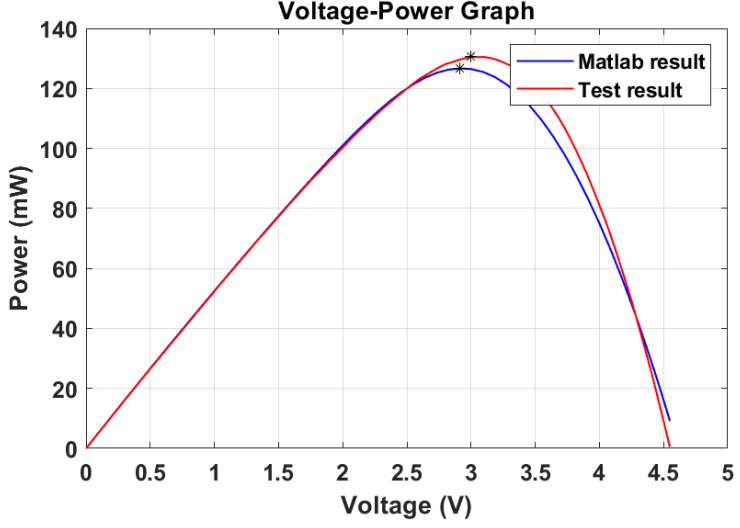

(b)

Fig. 8 Results for AgNW OPV (a) I-V; (b) P-V curves.

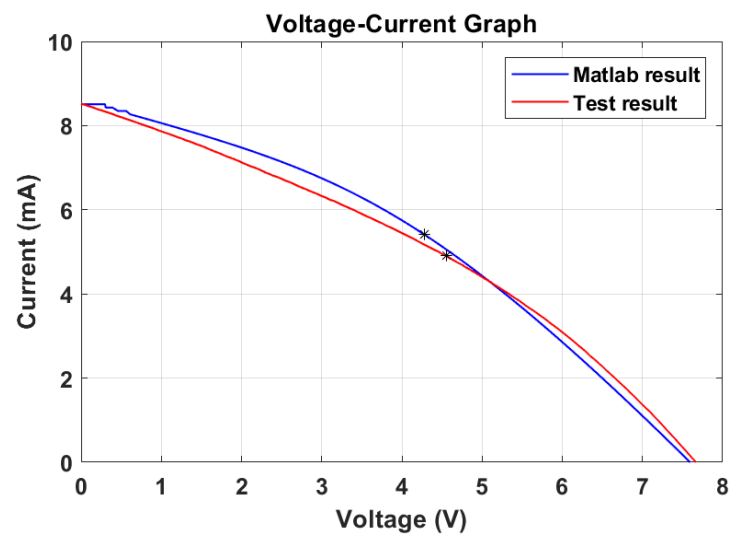

(a)

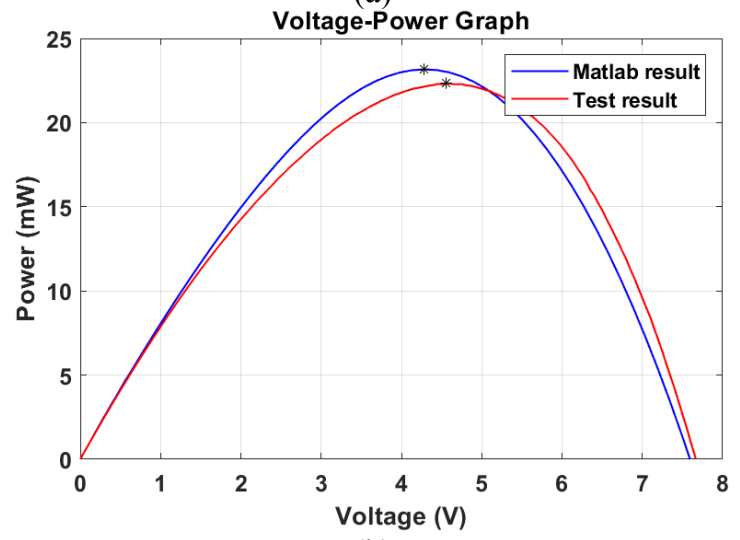

(b)

Fig. 9 Results for Carbon OPV cells (a) I-V; (b) P-V curves.

Table 4. Comparisons of OPV simulation and test results

\begin{tabular}{|c|c|c|c|c|}
\hline \multicolumn{2}{|c|}{} & $\begin{array}{c}\text { MATLAB } \\
\text { Simulink } \\
\text { result }\end{array}$ & $\begin{array}{c}\text { Outdoor test } \\
\text { result }\end{array}$ & $\begin{array}{c}\% \\
\text { error }\end{array}$ \\
\hline \multirow{4}{*}{ AgGrid } & FF & 0.43 & 0.42 & $2.4 \%$ \\
\cline { 2 - 5 } & $P_{m p}$ & $36.6 \mathrm{~mW}$ & $35.6 \mathrm{~mW}$ & $2.8 \%$ \\
\cline { 2 - 5 } & $V_{m p}$ & $2.68 \mathrm{~V}$ & $2.60 \mathrm{~V}$ & $3.1 \%$ \\
\cline { 2 - 5 } & $I_{m p}$ & $14.11 \mathrm{~mA}$ & $13.71 \mathrm{~mA}$ & $2.9 \%$ \\
\hline \multirow{3}{*}{ AgNW } & $\mathrm{FF}$ & 0.52 & 0.53 & $1.9 \%$ \\
\cline { 2 - 5 } & $P_{m p}$ & $126.7 \mathrm{~mW}$ & $130.54 \mathrm{~mW}$ & $2.9 \%$ \\
\cline { 2 - 5 } & $V_{m p}$ & $2.91 \mathrm{~V}$ & $3.0 \mathrm{~V}$ & $3.0 \%$ \\
\hline
\end{tabular}


Table 5. OPV large module parameters

\begin{tabular}{|c|c|c|}
\hline & $03 / 08 / 2018$ & $07 / 09 / 2018$ \\
\hline$T_{o t}$ & $21.6{ }^{\circ} \mathrm{C}$ & $14.4{ }^{\circ} \mathrm{C}$ \\
\hline$S$ & $300 \mathrm{~W} / \mathrm{m}^{2}$ & $300 \mathrm{~W} / \mathrm{m}^{2}$ \\
\hline Wind speed & $0.9 \mathrm{~m} / \mathrm{s}$ & $1.3 \mathrm{~m} / \mathrm{s}$ \\
\hline$k_{\text {ros }}$ & $0.023 \mathrm{~K}^{*} \mathrm{~m}^{2} / \mathrm{W}$ & $0.02 \mathrm{~K}^{*} \mathrm{~m}^{2} / \mathrm{W}$ \\
\hline$T_{c}$ & $28.42^{\circ} \mathrm{C}$ & $20.42{ }^{\circ} \mathrm{C}$ \\
\hline$N_{s}$ & 512 & 512 \\
\hline & & \\
\hline$N_{s h}$ & 1 & 1 \\
\hline$R_{s}$ & $11922 \Omega$ & $6345 \Omega$ \\
\hline$R_{s h}$ & $64719 \Omega$ & $55300 \Omega$ \\
\hline$V_{o c}$ & $283.8 \mathrm{~V}$ & $314.3 \mathrm{~V}$ \\
\hline$I_{s c}$ & $10.3 \mathrm{~mA}$ & $23.4 \mathrm{~mA}$ \\
\hline
\end{tabular}

\begin{tabular}{|c|c|c|c|c|}
\hline & $I_{m p}$ & $43.50 \mathrm{~mA}$ & $43.51 \mathrm{~mA}$ & 0 \\
\hline \multirow{4}{*}{ Carbon } & $\mathrm{FF}$ & 0.36 & 0.34 & $5.9 \%$ \\
\cline { 2 - 5 } & $P_{m p}$ & $23.2 \mathrm{~mW}$ & $22.3 \mathrm{~mW}$ & $4.0 \%$ \\
\cline { 2 - 5 } & $V_{m p}$ & $4.13 \mathrm{~V}$ & $4.55 \mathrm{~V}$ & $9.2 \%$ \\
\cline { 2 - 5 } & $I_{m p}$ & $5.34 \mathrm{~mA}$ & $4.9 \mathrm{~mA}$ & $8.9 \%$ \\
\hline
\end{tabular}

\section{Simulation Results for Modules}

A similar analysis was repeated for a larger OPV module, including 512 cells connected in series. The aim of this work was to assess if the proposed model can be scaled up while still maintaining accuracy. The parameters for the module are shown in Table 5: these parameters correspond to two days, characterised by different temperature and wind speed.

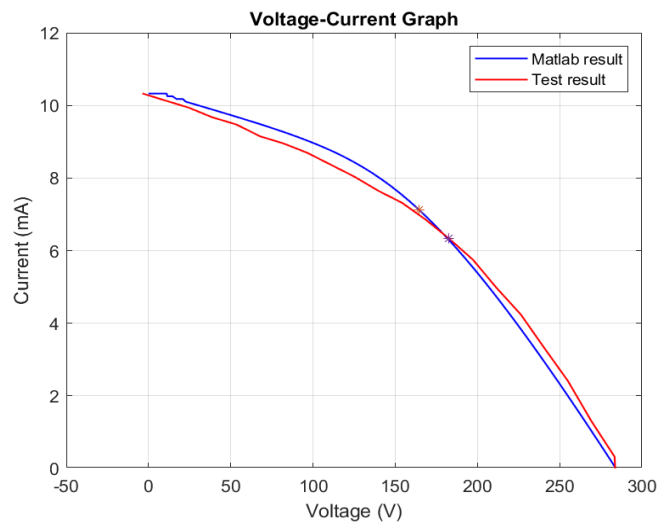

(a)

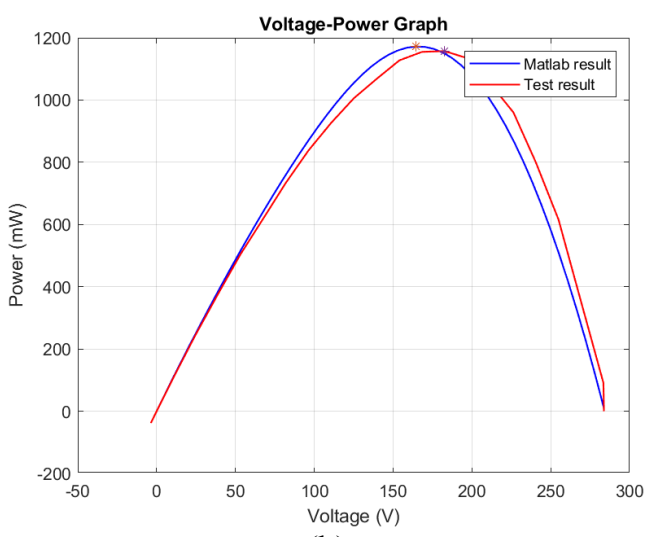

(b)

Fig. 10 Results for large module OPV in 03/08/2018: (a) I$\mathrm{V}$; (b) P-V curves.

Fig. 10 and 11 show the comparison of simulation and experimental results. It can be seen that the I-V and P-V curves still match closely, and Table 6 summaries the key parameters comparison results. In both days, the error between the computer simulation and outdoor test is less than $4 \%$.

Therefore, the analysis carried out in this section allows concluding that the proposed computer model can be extended to larger panels but still maintain in a small match error. Additional cases where run for additional days, and varying operating conditions, and they led to similar conclusions.

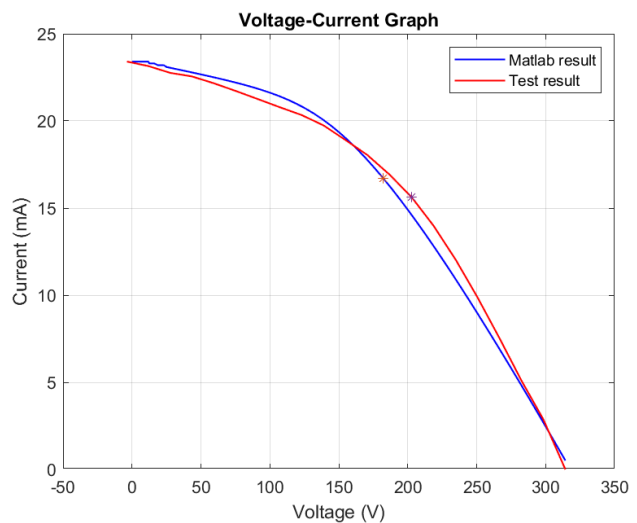

(a)

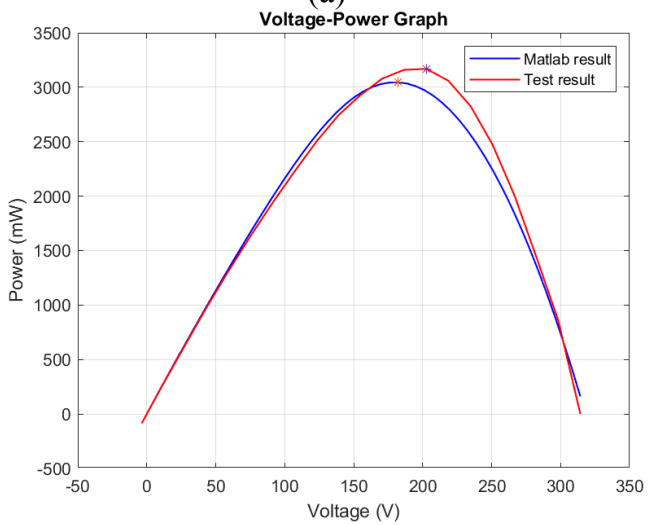

(b)

Fig. 11 Results for large module OPV in 07/09/2018: (a) I$\mathrm{V}$; (b) P-V curves. 
Table 6. Comparisons of large module OPV simulation and test results in two selected days

\begin{tabular}{|c|c|c|c|c|}
\hline \multicolumn{2}{|c|}{} & $\begin{array}{c}\text { MATLAB / } \\
\text { Simulink } \\
\text { result }\end{array}$ & $\begin{array}{c}\text { Outdoor test } \\
\text { result }\end{array}$ & $\begin{array}{c}\% \\
\text { error }\end{array}$ \\
\hline $\begin{array}{c}03 / 08 \\
12018\end{array}$ & FF & 0.4 & 0.4 & \multirow{2}{*}{$1.2 \%$} \\
\cline { 2 - 4 } $07 / 09$ & $P_{m p}$ & $1172 \mathrm{~mW}$ & $1157 \mathrm{~mW}$ & \\
\cline { 2 - 4 }$/ 2018$ & $P_{m p}$ & $3045.1 \mathrm{~mW}$ & $3168.9 \mathrm{~mW}$ & \multirow{2}{*}{$3.9 \%$} \\
\hline
\end{tabular}

\section{Conclusions}

A computational PV model was proposed in the paper, that allow representing accurately low fill factor OPV cells by using computer software. The mathematical equations behind the model were presented and the calculation of the cells parameters was described, with particular attention to the calculation of the cell temperature based on the Ross coefficient.

Initially, the proposed model was validated by using outdoor test data for three OPV cells. The comparison demonstrated a good accuracy, and therefore the analysis was extended to a larger module, including 512 cells. For the large module, the comparison of simulation results to outdoor test data allowed confirming the validity of the proposed model.

The results presented in this paper are only representative of a few operating conditions, but additional comparisons were carried out further confirming the validity of the proposed model. This model can be used within computer simulations to evaluate the performance of the OPV cells under varying operating conditions, in terms of irradiance, wind speed and temperature.

The next step of the research will consist in applying the computer model to a hardware platform, to emulate the PV cell features using HiL (hardware-in-the-loop) analysis. Additionally, the degradation of the OPV cell performance will be assessed by calculating the cell parameters for measurements taken across a long period of time.

\section{Acknowledgment}

The authors would like to acknowledge funding by the European Regional Development Fund, through the Welsh Government, for the 2nd Solar Photovoltaic Academic Research Consortium (SPARC II) which supported this research.

The authors would like to acknowledge funding by the Supergen Energy Storage Network + Travel and Conference Grants 2020 (Round 1) which supported this research.

\section{References}

[1] S. Lo Piano, and K. Mayumi, "Toward an integrated assessment of the performance of photovoltaic power stations for electricity generation," Applied Energy, vol. 186, pp. 167-174, 2017/01/15/, 2017.

[2] I. Rasoanarivo, "Implementation of Standalone PV Micro Grid with Multi-level converters for Rural Electrification," 7th International
Conference on Renewable Energy Research and Applications (ICRERA), pp. 88-93, 2018.

[3] K. Naceur, "Tracking Clean Energy Progress," International Energy Agency, Paris, France, 2016.

[4] A. Belkaid, I. Colak, K. Kayisli, M. Sara, and R. Bayindir, "Modeling and Simulation of Polycrystalline Silicon Photovoltaic Cells," 7th International Conference on Smart Grid (icSmartGrid), pp. 155-158, 2019.

[5] G. Conibeer, "Third-generation photovoltaics," Materials Today, vol. 10, no. 11, pp. 42-50, 2007.

[6] J. P. Ram, H. Manghani, D. S. Pillai, T. S. Babu, M. Miyatake, and N. Rajasekar, "Analysis on solar PV emulators: A review," Renewable and Sustainable Energy Reviews, vol. 81, pp. 149-160, 2018.

[7] W. Yin, Q. Tong, Y. Xu, Y. Zhang, and Y. Zhou, "Partial Shading Impact on PV Array System and the Hard-Shading Location with BP Algorithm," 7th International Conference on Smart Grid (icSmartGrid), pp. 21-26, 2019.

[8] M. Caruso, R. Miceli, P. Romano, E. R. Sanseverino, G. Schettino, F. Viola, and T. N. Ngoc, "Comparison between Different Dynamic Reconfigurations of Electrical Connections for partially shaded PV Modules." 2018 International Conference on Smart Grid (icSmartGrid), Nagasaki, Japan, pp. 220-227.

[9] E. Kurt, and G. Soykan, "Performance Analysis of DC Grid Connected PV System Under Irradiation and Temperature Variations," 8th International Conference on Renewable Energy Research and Applications (ICRERA), pp. 702-707, 2019.

[10] J. A. Gow, and C. D. Manning, "Development of a photovoltaic array model for use in power-electronics simulation studies," IEE Proceedings: Electric Power Applications, vol. 146, no. 2, pp. 193-200, 1999.

[11] O. Mesbahi, M. Tlemçani, F. Janeiro, A. Hajjaji, and K. Kandoussi, “A Modified Nelder-Mead Algorithm for Photovoltaic Parameters Identification," Int. Journal of Smart Grids, vol. 4, 2020.

[12] R. Ayop, and C. W. Tan, "Rapid Prototyping of Photovoltaic Emulator Using Buck Converter Based on Fast Convergence Resistance Feedback Method," IEEE Transactions on Power Electronics, vol. 34, no. 9, pp. 8715-8723, 2019.

[13]N. Ullah, F. Nisar, and A. A. Alahmadi, "Closed Loop Control of Photo Voltaic Emulator Using Fractional Calculus," IEEE Access, vol. 8, pp. 28880-28887, 2020.

[14]R. Ayop, and C. W. Tan, "A comprehensive review on photovoltaic emulator," Renew. Sust. Energ. Rev., vol. 80, pp. 430-452, 2017/12/01/, 2017.

[15]M. C. Di Piazza, and G. Vitale, Photovoltaic sources: modeling and emulation: Springer Science \& Business Media, 2012.

[16]K. Ishaque, Z. Salam, and Syafaruddin, "A comprehensive MATLAB Simulink PV system simulator with partial shading capability based on two-diode model," Solar Energy, vol. 85, no. 9, pp. 2217-2227, 2011/09/01/, 2011.

[17]H. Nagayoshi, S. Orio, Y. Kono, and H. Nakajima, "Novel PV array/module I-V curve simulator circuit." The 29th IEEE Photovoltaic Specialists Conference, 2002., New Orleans, LA, USA, 2002 , pp. 15351538.

[18]N. Bristow, and J. Kettle, "Outdoor organic photovoltaic module characteristics: Benchmarking against other PV technologies for performance, calculation of Ross coefficient and outdoor stability monitoring," Solar Energy Materials and Solar Cells, vol. 175, pp. 52$59,2018$.

[19] N. Tutkun, E. Elibol, and D. Maden, "Basic parameter extraction from an organic solar cell through the single diode model and a metaheuristic technique with the Lambert W function." International Renewable and Sustainable Energy Conference (IRSEC), Ouarzazate, 2014, pp. 554558.

[20]A. D. Dhass, E. Natarajan, and L. Ponnusamy, "Influence of shunt resistance on the performance of solar photovoltaic cell," International Conference on Emerging Trends in Electrical Engineering and Energy Management (ICETEEEM), pp. 382-386, 2012.

[21]B. Ray, and M. A. Alam, "Achieving fill factor above $80 \%$ in organic solar cells by charged interface." IEEE Journal of Photovoltaics, vol. 3 , no. 1 , pp. 310-317. 